Jochen Oltmer

\section{Migration: Geschichte und Zukunft der Gegenwart}

Darmstadt: Konrad Theiss Verlag (WBG), 2017, 288 str.

DOI: https://doi.org/10.11567/met.33.1.4

Izvanredni profesor novije povijesti na Sveučilištu Osnabrück i član predsjedništva Instituta za istraživanje migracija i interkulturne studije (Institut für Migrationsforschung und Interkulturelle Studien) pri istom sveučilištu Jochen Oltmer u svojim se istraživanjima bavi poviješću migracija i migracijskom politikom od 18. stoljeća do suvremenosti. Utemeljitelj je tog instituta Klaus J. Bade, profesor emeritus i istaknuti stručnjak za istraživanje migracija, stanovništva, azila, migracijskih politika, pitanja integracije i manjina. S J. Oltmerom i nekolicinom drugih stručnjaka urednik je zapaženoga referentnog djela o migracijama Enzyklopädie Migration in Europa: Vom 17. Jahrhundert bis zur Gegenwart, koje je doživjelo nekoliko izdanja. Jochen Oltmer objavio je brojne radove iz toga istraživačkog područja, a knjiga Migration: Geschichte und Zukunft der Gegenwart koju je objavio Konrad Theiss Verlag 2017. nadopunjena je i proširena verzija drugog izdanja knjige Globale Migration: Geschichte und Gegenwart iz 2016. (München: C. H. Beck).

U knjizi Migration: Geschichte und Zukunft der Gegenwart, koja je podijeljena u devet poglavlja, autor se fokusira na njemačku, europsku i globalnu migracijsku situaciju te na demografske, gospodarske, političke, društvene i okolišne promjene koje nastaju kao posljedica prostorne pokretljivosti ljudi. Oltmer promatra migracije kao fenomen koji je oduvijek prisutan u ljudskoj povijesti i koji ju je obilježio. Osvrće se na rasprave o migracijskim prilikama krajem 20. i početkom 21. stoljeća, kako u svijetu tako i u Europi, i upozorava na sve veću važnost koja se danas pridaje tom pitanju. Osobitu pozornost, i stručne i šire javnosti, privukla je migracijska kriza 2015., a posebice izbjegličko pitanje te njegove društvene, sigurnosne, političke i kulturne posljedice za Njemačku, ali i za Europsku uniju u cjelini.

Autorovo je stajalište da se sadašnjost i budućnost Europe i svijeta mogu opisati kroz promjene migracijskih odnosa i stoga svoje istraživanje migracija temelji na povijesnom pristupu. Naglašava da je u ranim devedesetim godinama 20 . stoljeća počeo pojačan interes povijesne znanosti za istraživanje migracija. Pritom ističe da su seobe oduvijek mijenjale svijet te da je »kretanje u prostoru od početka čovječanstva bilo središnji element prilagodbe na okolišne uvjete i društvene promjene - istovremeno mijenjajući okoliš i društvo« (str. 8). Pozivajući se na Klausa J. Badea, autor ističe kako bez kretanja u prostoru ljudska vrsta ne bi mogla opstati desecima tisuća godina te izražava suglasnost $\mathrm{s}$ Badeovom tvrdnjom da homo sapiens postoji otkad postoji homo migrans.

Uvodni dio sadržava zanimljive i korisne podatke o latinskom podrijetlu pojma »migracija « te o njegovu preuzimanju, primjeni i značenju u njemačkom jeziku. Raspravu o pojmovima kojim se označivalo kretanje u prostoru autor uvodno nadopunjuje pristupima i područjima povijesnog istraživanja migracija. Iako je u istraživanju migracija iz povijesne perspektive dominiralo razdoblje 19. i 20 sto- 
ljeća, ističe noviju tendenciju proučavanja i prethodnih razdoblja - od ranoga novog vijeka preko srednjeg vijeka do antike - kako bi se dobila sveobuhvatna povijesna slika migracijskog fenomena. Za istraživanje tih povijesnih procesa i struktura mogu se upotrijebiti različiti izvori (statistički podaci, dokumenti različitih institucija, ego-dokumenti, vizualni materijali i dr.) i primijeniti različite metode (hermeneutička, kvantitativna, analiza sadržaja i dr.).

Predmet povijesnog bavljenja migracijama jesu migracijski procesi, bilo da im je cilj trajno naseljavanje, bilo da je riječ o sezonskim ili cirkularnim kretanjima, dok se u novije vrijeme pozornost usmjeruje na razvoj migracijskih sustava pod kojima se podrazumijevaju dugotrajne i stabilne migracijske veze između zemlje podrijetla i zemlje primitka. Povijesno istraživanje migracija, smatra Oltmer, može zahvatiti cjelokupnu migracijsku situaciju u nekom prostoru i pritom rasvijetliti uzajamno djelovanje različitih migracijskih oblika u specifičnim društvenim, ekonomskim, političkim i demografskim konstelacijama.

Široka je lepeza istraživačkih pitanja i područja kojima se bavi povijesno istraživanje migracija: od rasvjetljavanja uzroka migracija i obrazaca prostornoga kretanja preko opisivanja iskustava i životnih uvjeta migranata u zemlji primitka do istraživanja identiteta migranata i njihove integracije, uključujući utjecaj države na navedene procese te njihov utjecaj na obitelji migranata i zemlju njihova podrijetla.

Kao što sam autor kaže, cilj knjige jest pokazati povijesne promjene u dugom trajanju, temeljne uvjete migracija, njihove pojavne oblike i po- sljedice. Pritom izražava nadu da bi njegova analiza mogla pridonijeti ne samo sagledavanju aktualne migracijske situacije nego i razvijanju strategija za pristup tom problemu u budućnosti.

U drugom poglavlju Oltmer raščlanjuje migracije kao globalni fenomen i istražuje njihove uzroke, motive i mreže koje se njima stvaraju, oblike u kojima se javljaju te načine na koje ih reguliraju različite državne, nadnacionalne i međunarodne institucije.

U sljedećim poglavljima autor prikazuje obrasce njemačkih, europskih i svjetskih migracija od ranoga novog vijeka i otkrića »Novoga svijeta do situacije s migracijskim valom prema Europi 2015. Postupno i na konkretnim primjerima opisuje promjene migracijskih prilika svodeći ih na širok spektar gospodarskih, društvenih, političkih i kulturnih uzroka i uvjeta. Pritom veću pozornost usmjeruje na ona razdoblja i područja u kojima su migracije ubrzale društvene promjene, a to se dogodilo zato što migracije imaju potencijal za koncentraciju društvene interakcije koja pokreće transformaciju stanovništva, gospodarstva i društva. Migracije od 16. do 18. stoljeća utjecale su na velike promjene u stanovništvu obiju Amerika i Europe. Autor uspješno pokazuje kako je političko-teritorijalna ekspanzija Europe od kasnog 15. stoljeća korespondirala s odseljavanjem Europljana u druge dijelove svijeta. Opisujući dinamiku i učinke te ekspanzije, dovodi je u vezu s populacijskim stagnacijama i rastom u Europi. Najbolja su ilustracija tih procesa podaci o broju stanovnika na svijetu i udjelu pojedinih dijelova svijeta u ukupnoj populaciji na Zemlji. Ocrtavajući postupnu europsku kolonizaciju Novoga svijeta, izno- 
si podatak da je od kraja 15. do kraja 18. stoljeća Europu napustilo između osam i devet milijuna ljudi - uglavnom pomorskih ili vojnih radnih migranata. Različite politike naseljavanja koje su europske kolonijalne sile provodile u svojim kolonijama u Južnoj i Sjevernoj Americi rezultirale su i različitim razvojem na sjeveru i jugu tih kontinenata. $S$ tim u vezi nezaobilazno je pitanje posljedica koje su prisilno naseljavanje afričkih robova, robovski rad i trgovina robljem imali za Afriku, obje Amerike te za prostor Indijskog oceana.

Posebnu pozornost autor posvećuje iseljavanju iz njemačkoga govornog područja u prekomorske zemlje, ali i $\mathrm{u}$ istočne, jugoistočne i srednjoistočne dijelove Europe u 18. stoljeću, potkrepljujući svoju analizu brojnim statističkim podacima o broju iseljenih, njihovu socijalnom sastavu i regionalnom podrijetlu. Zanimljiv je podatak da se od osamdesetih godina 17. stoljeća do 1800. oko 516.000 ljudi iz njemačkoga govornog područja odselilo prema navedenim dijelovima Europe, a u prekomorskom iseljavanju prema Sjevernoj Americi u tom je razdoblju sudjelovalo oko 130.000 ljudi iz njemačkoga etničkog prostora. Razmatrajući odnos europskih migracija i njemačkoga govornog područja, Oltmer zaključuje da se može govoriti o političkom konceptu u čijoj je osnovi bila migracijska politika nadahnuta merkantilizmom. U tom kontekstu promatra i proces koji je u njemačkoj stručnoj terminologiji poznat kao Peuplierung (što bismo mogli prevesti kao »kolonizacija«). Riječ je o procesu (koji počinje već u 17 . stoljeću) napučivanja slabo naseljenih istočnih dijelova njemačkoga etničkog prostora radno i porezno sposobnim podanicima (npr. protjeranim protestantima iz Francuske i Austrije).

Četvrto se poglavlje bavi masovnim migracijama $\mathrm{u}$ »dugom 19. stoljeću«. Autor analizira europsku - osobito njemačku - prekooceansku migraciju. Usredotočuje se na Sjedinjene Američke Države, koje krajem 19. stoljeća postaju najsnažnija industrijska i gospodarska sila svijeta s produktivnim agrarnim sektorom i razvijenom mrežom prometnica. O snazi transatlantske migracije svjedoči i podatak da se od 1815. do 1930. iz Europe iselilo oko 55 do 60 milijuna ljudi, od čega dvije trećine u Sjevernu Ameriku. U tom poglavlju Oltmer spretno prikazuje međuovisnost ekonomskih i demografskih čimbenika na jednoj i migracije na drugoj strani te identificira potisne i privlačne čimbenike te masovne seobe. Pritom ističe pravilnu isprekidanost razdoblja konjunkture razdobljima ekonomske stagnacije te utjecaj te dinamike na formiranje migracijskih i useljeničkih politika.

Sljedeće je poglavlje posvećeno radnim migracijama u Njemačkoj i Europi 19. stoljeća - procesu koji je tijesno povezan s procesima industrijalizacije i modernizacije poljoprivredne proizvodnje. Temeljne promjene demografskih pokazatelja (osobito činjenica da se stanovništvo Europe u razdoblju od stotinjak godina povećalo dva i pol puta), porast broja velikih gradova, naglo povećanje udjela gradskog stanovništva u odnosu na seosko te promjena društvene strukture gradova - najvažniji su učinci ubrzane urbanizacije Staroga kontinenta, osobito njegovih zapadnih i središnjih dijelova. Izrazita prostorna mobilnost karakterizirala je proces urbanizacije, ali i modernizacije agrarnog sektora, dok je pojačana industrijalizacija ima- 
la za posljedicu internacionalizaciju tržišta rada.

Kolonijalizam i izgradnju državnih struktura $u$ ovisnim zemljama krajem 19. i početkom 20. stoljeća te posljedice koje je kolonijalna politika imala na kolonije i na matične zemlje autor obrađuje u zasebnom poglavlju. Pritom se fokusira na nove europske iseljeničke destinacije - poput Argentine i Sibira - te na migracije potaknute otkrićem novih unosnih resursa kao što su zlato i dijamanti u Africi. Na slikovit način opisuje i novi oblik globalnog sustava radne migracije koji je svoje korijene imao u britanskoj Indiji. Za ilustraciju toga novog ekonomskog trenda navodi čitav niz primjera, među kojima vrijedi izdvojiti onaj indijskih ugovornih radnika (Coolies) koji su radili na plantažama šećerne trske na Mauricijusu.

Naredna dva poglavlja posvećena su prisilnim migracijama koje su obilježile prvu polovinu 20. stoljeća. »Bijeg«, »progon« i »deportacija« izrazi su za kojima autor poseže radi objašnjenja najmasovnijih prisilnih migracija u 20. stoljeću. Sliku prve polovine 20. stoljeća, obilježene dvama svjetskim ratovima te velikom ekonomskom krizom u međuratnom razdoblju, autor promatra kroz prizmu migracija, uglavnom prisilnih, i neumoljivih brojčanih pokazatelja. Utjecaj hladnoratovske politike na ograničenja prekograničnih kretanja u kombinaciji s rastućim tržištima poslijeratne Europe i potrebom za novom radnom snagom čimbenici su koji igraju ključnu ulogu u njegovoj analizi migracija u drugoj polovini 20. stoljeća.
U zadnjem se poglavlju autor bavi suvremenim migracijama krajem 20. i početkom 21. stoljeća. U Europi su se one nakon pada Berlinskog zida uglavnom odvijale u smjeru istok zapad, a motivirane su ekonomskim razlozima. To je razdoblje obilježeno i valom izbjeglica početkom devedesetih s prostora bivše Jugoslavije. Osim recentnome izbjegličkom valu s Bliskog istoka i iz Afrike, kojim Oltmer završava svoj pregled svjetske povijesti kroz vizuru prostorne pokretljivosti, dužnu pozornost posvećuje i utjecaju klimatskih promjena i promjena u okolišu na globalne migracije. Analizirajući dinamiku suvremenih migracija, promatra ih $\mathrm{u}$ svjetlu rasta gradova, ali i velikog porasta stanovništva na globalnoj razini.

Zaključno možemo reći da knjiga Jochena Oltmera nudi dobar povijesni pregled migracija, osvjetljujući taj fenomen iz različitih perspektiva i potkrepljujući teorijske uvide raznovrsnim empirijskim podacima. Izoštravajući pogled prema onim migracijskim procesima koji su svojim razmjerom, ulogom i posljedicama ostavili najdublji trag u aktualnoj slici svijeta, autor uspijeva čitatelju pružiti uvid u čimbenike i silnice koji su oblikovali ljudsku povijest kao povijest migracija. Stoga se ova knjiga, osim stručnjacima različitih disciplina koji se bave migracijama, može preporučiti i široj publici, osobito onoj sklonoj da u prošlosti traži odgovore na pitanja koja su sastavni dio današnjih vijesti. Naravno, preduvjet je poznavanje njemačkog jezika.

\section{Sanja Lazanin}

Institut za migracije i narodnosti, Zagreb 